Results obtained were the following : a high and early morbidity in piglets born from control sows and in those from vaccinated and non booster injected sows. The mortality rate 7 days after challenge exposure was 96 and 58 p. 100, respectively. Conversely, morbidity was low in piglets from vaccinated and booster injected sows. In the latter the mortality rate was 25 p. 100 . A more severe control of some parameters (dates of vaccination and booster injection) and of the stress factors after farrowing might lead to a better protection of the animals.

\title{
Non specific defenses against transmissible gastroenteritis in pigs. Study of virus-lymphocyte interactions
}

\author{
B. CHARLEY, H. LAUDE, C. LA BONNARDIERE \\ I.N.R.A., Station de Recherches de Virologie et d'Immunologie, \\ 78850 Thiverval-Grignon
}

Transmissible Gastroenteritis virus (TGEV) primarily infects enterocytes of the small intestine. However, other cells involved in host immune defenses also interact with TGEV; these cells are macrophages and lymphocytes. Concerning lymphocytes, TGEV, although unable to infect these cells, induces interferon production. Non immune pig lymphocytes have also a non specific antiviral effect since they inhibit viral replication and kill virus infected cells in vitro.

\section{Importance of streptococcal disease (Streptococcus suis, group R) in France}

\author{
Josée VAISSAIRE *, C. MARCON **, Marylène KOBISCH ***, \\ Marguerite LE MENEC ****, R. CARNERO*, Micheline LAROCHE *, \\ Ginette MIRIAL * \\ * Ministère de l'Agriculture, Laboratoire Central de Recherches Vétérinaires, \\ 22, rue Pierre-Curie, B.P. 67, 94703 Maisons-Alfort \\ ** Sanders S.A., 17, quai de l'Industrie, 91201 Athis-Mons \\ *** Ministère de l'Agriculture, Station de Pathologie Porcine, B.P. 9, \\ 22440 Ploufragan
}

**** Ministère de l'Agriculture, Laboratoire Vétérinaire Départemental des Côtes-du-Nord, 8, place du 74"-R.I.T., B.P. 14, 22021 Saint-Brieuc Cedex

The streptococcal disease, Streptococcus suis (Lancefield's R group) is an important pathological problem in French pig production. The illness appears as soon as the pigs are grouped in post weaning or fattening farms and can be transmitted to man. It causes septicaemias, bronchopneumonias, endocarditis, polyserotis, arthritis and even diarrhoea in the pig. The morbidity and mortality may be high. Exsudative and acute inflammatory lesions are observed. Application of the treatment and of prophylactic measures is difficult. At the laboratory, 340 out of the 455 Streptococcus strains isolated from healthy and ill pigs belonged to Streptococcus suis (group R), i.e. about 75 p. 100 . The other 115 strains belonged to Lancefield's C, E, L, G, B groups and to Streptococcus uberis. Animals aged five to twelve weeks were the most affected. This Streptococcus is a capsulated diplococcus ; eight serotypes seem to coexist in France. This germ is very close to human pneu- 